\title{
EFFECT OF FRICTION STIR WELDING PARAMETERS ON THE IMPACT ENERGY TOUGHNESS OF THE 6061-T6 ALUMINUM ALLOYS
}

\author{
E. T. B. Karash ${ }^{*}$, S. R. Yassen ${ }^{2}$, M. T. E. Kassim 1 \\ ${ }^{1}$ Northern Technical University, Mosul, Iraq \\ ${ }^{2}$ University of Salahaddin, Kirkuk Road, Erbil Kurdistan Region, 44002-Erbil, Iraq \\ *Corresponding author's e-mail address: emadbane2007@yahoo.com
}

\begin{abstract}
This research focused on studying the influence of friction stir welding (FSW) factors - such as the type of the welding tool, the speed of the welding tool and the welding speed - on the impact toughness of the panels made of AA6061 - T6 aluminum alloy sheets with thickness of $3 \mathrm{~mm}$. The aluminum alloys have multiple uses in industry, but are quite difficult to be welded by fusion welding processes, including MIG welding, and laser welding. By using a milling machine, it was possible to employ the FSW process, applying four constant welding speeds $(800,1000,1250,1600 \mathrm{rpm})$ and three welding speeds $(32,63,80 \mathrm{~mm} / \mathrm{min})$. Tool pins with square cylindrical and threaded tapered cylindrical profiles were used in the experimental programme. The machined samples were subjected to Charpy V notch impact test at room temperature and the results were compared to the impact energy of the base metal. The results show higher values of the impact energy when the tool pin used has square profile.
\end{abstract}

KEYWORDS: aluminum alloy, friction stir welding, impact toughness, rotational speed, welding speed.

\section{ACKNOWLEDGMENTS}

This research was supported by the Engineering Science Research Program through the Mechanical Department College of Engineering - the University of Mosul and funded by the Ministry of Higher Education and Scientific Research from Republic of Iraq.through the grant no. 2017-00333.

\section{REFERENCES}

[1] Akula D. R., Characterization of Mechanical Properties and Study of Microstructure of Friction Stir Welded Joints Fabricated from Similar and Dissimilar Alloy of Aluminum, BSc thesis, University of Missouri-Columbia, December 2007.

[2] Adesola A. O., Odeshi A. G., A comparative study of the compressive behavior of 2099-T6 and 6061-T6 aluminum alloys under quasistatic and dynamic shock loading, in conference proceedings, Materials Science and Technology (MS\&T) 2010, October 17-21, 2010, Houston, Texas, pp. 2075 - 2084.

[3] Lohwasser D., Chen Z., Friction Stir Welding from Basics to Applications, Wood head Publishing Limited, Abington Hall, Great Abington, Cambridge CB21 6AH, UK, 2010.

[4] Mulapeer M. M., Metallurgical and Mechanical Properties for Friction Stir Welding Aluminum Alloys, Degree of Doctor, University of Salahaddin-Erbil, October 2009.

[5] Ambriz R. R., Mayagoitia V., Welding of Aluminum Alloys, Institute Politecnico, Azcapotzalco, DF, Mexico, 2010.

[6] Mishra R. S., Mahoney M. W., Friction Stir Welding and Processing, Rockwell scientific company, 2007.

[7] Birsan D., Scutelnicu E., Modelling of thermo-mechanical effects generated by friction spot stir welding process, Welding Equipment and Technology, ISSN 1221-4639, Vol. 25, Year XXV, Galati University Press, 2014.

[8] Boiocchi F., Friction Stir Spot Welding Applied to TP AA6061-T4 sheet metals, Metal Working World Magazine, 15 March, 2014.

[9] Hakem M. et. al., Heat Treatment and Welding Effects on Mechanical Properties and Microstructure Evolution of 2024 and 7075 Aluminum Alloys, Metal, Hradec and Moravia, 2008.

[10] Sakthivel T., Senger G. S., Effect of Welding Speed on Microstructure and Mechanical Properties of Friction Stir Welded Aluminum, Springer -Verlag London Limited, 2008.

[11] Ali W. J., Ismael Q. H., Effect of Friction Stir Welding Parameters on the Impact Energy of the Elements of Poorly Wieldable Aluminum Alloys by Fusion Welding, Al-Rafidain Engineering Vol.21 No. 6, 2013.

[12] Mustafa Kemal Kulekci., Experimental comparison of MIG and Friction Stir Welding processes for EN AW-6061-T6 (Al Mg Si Cu) Aluminum Alloys, The Arabian Journal for Science and Engineering. Vol. 35, No.1B, April 2010. 
[13] Raghu Babu G. et. al., An Experimental Study on the Effect of Welding Parameters on Mechanical and Microstructural Properties of AA6082-T6 Friction Stir Welded Butt Joints, Arpin Journal of Engineering and Applied Sciences, Vol.3, No.5, 2008.

[14] *** ASTM E3-01, Standard Guide for Preparation of Metallographic Specimens, USA. 